\title{
Exploring the Perceived Career Success of Staff in a South African Science and Engineering Company
}

\author{
Didi-Mari du Toit and Melinde Coetzee \\ University of South Africa
}

\begin{abstract}
This study explored the core themes underlying individuals' perceptions of their career success with the view to inform retention practices. The participants were a convenience sample of 207 employees (63\% Blacks; $60 \%$ males) within a South African science and engineering company. Data were gathered by using a quantitative survey approach and posing an open-ended question to the participants regarding their perceived career success. The data were thematically analysed by using the Atlas.ti version 6 computer-aided qualitative data analysis software. Findings suggest that self-perceptions of career success are multifaceted, including learning and development; skills, experience and competence; career transitions and advancement; job content; contributing to a larger community; goal achievement; helping others; rewards and recognition; and work-life balance. Individuals' inner definitions of career success could inform retention strategies in the science and engineering field focused on their career development, career wellbeing and satisfaction.
\end{abstract}

- Keywords: objective career success, subjective career success, career development, retention

The retention of staff possessing high technology (for example, science and engineering) skills has become of strategic importance as employers struggle to retain their valuable knowledge workers due to a general shortage of experienced and skilled candidates and aggressive recruitment tactics by others in the high technology arena (Döckel, Basson, \& Coetzee, 2006). In addition, such industries operate in volatile markets and experience accelerating growth and rates of change. Employees with technology skills have a strong preference for independence and hold a large portion of the organisation's intellectual capital (Murphy, 2000). Employees in the science and engineering field may identify with a high technology culture separate from the organisation in which he or she works (Döckel et al., 2006; Rogers, 2001). This professional focus could lead to a loyalty clash. For instance, high technology skill employees may prefer to work on projects that enhance their careers, knowledge assets and future earning power, while the organisation generally wants current knowledge applied to developing value-added products. This clash is a common source of problems for firms wanting to retain workers in the high technology field (Von Glinow \& Mohrman, 1990).

The foregoing trends in the high technology sector have led to a renewed interest in the organisational and individual factors that influence people's personal evaluations of their career success (Coetzee, Bergh, \& Schreuder, 2010; Sinclair, 2009). Powell and Snellman (2004) state that to understand careers in the knowledge economy better, more importance need to be ascribed to the subjective career. Given the information-based economies' reliance on knowledge-intensive and intellectual capabilities, understanding individuals' own interpretations of their careers has become imperative (Khapova, Arthur, \& Wilderom, 2007).

Careers have become less ordered and predictable (Arnold \& Cohen, 2008; Arthur, Khapova, \& Wilderom,

ADDRESS FOR CORRESPONDENCE: Professor Melinde Coetzee, Department of Industrial \& Organisational Psychology, PO Box 392, University of South Africa, 0003. E-mail: coetzm1@unisa.ac.za 
2005; Coetzee \& Bergh, 2009; Hall \& Chandler, 2005; Kidd, 2008; Sinclair, 2009) due to their subjective and emergent nature resulting from the ever-changing demands of the information-based economies. However, there seems to be a paucity of research on how people in the high technology sector interpret their career success, especially in the African settings (du Toit, 2010).

\section{Subjective and Objective Aspects of Career Success}

Careers involve both objective and subjective perspectives (Khapova et al., 2007; see Figure 1). Objective career success reflects individuals' own interpretations of how well they have done in terms of rewards, promotions, recognition and other such visible indicators (Peiperl \& Jonsen, 2007). Objective career success is generally measured in terms of remuneration, increases, promotions, bonuses, job titles, rank and allowances received from the organisation. These are factors over which individuals exercise limited control. Objective career success criteria are therefore viewed from an external perspective and judged by other people (Sinclair, 2009).

Subjective career success reflects an individual's perception of their own success (e.g., work role, interpersonal success) and self-evaluations of career success, not only in an employee's current organisation, but also during their career in general (e.g., satisfaction, sense of accomplishment and sense of self-worth) (Nabi, 2003; Peiperl \& Jonsen,
2007). Individuals exhibiting higher subjective career success tend to feel happier and more successful about their careers relative to their own internal standard (Nabi, 2003). Subjective career success has also been found to have important implications for individuals' psychological and career wellbeing and quality of working life (Kidd, 2008; Nabi, 2003; Peluchette, 1993). Thus, one of the key factors distinguishing subjective career success from objective career success is its focus on perceptions of satisfaction rather than actual career advancements (Kuznia, Kerno, \& Gilley, 2010). Kidd (2008) suggests that the term career wellbeing should replace the term career success when referring to an individual's experience of his or her own career, thus eliminating the emphasis on performance-related outcomes.

Schreuder and Coetzee (2011) note that subjective career success is also associated with mastering ambiguity as individuals are obliged to respond to the current fast-changing, uncertain and unpredictable nature of careers. Mastering ambiguity enables people to adapt and respond effectively to changes in the external environment by empowering themselves with knowledge and creativity. Subjective career success is also assessed in terms of the learning that has taken place and the multitude of skills a person has acquired. It is these skills that sustain individuals' employability and make them indispensable to an organisation in a knowledge economy (Coetzee \& Schreuder, 2011).

The objective and subjective career are interdependent; in other words, they coexist and influence one another.

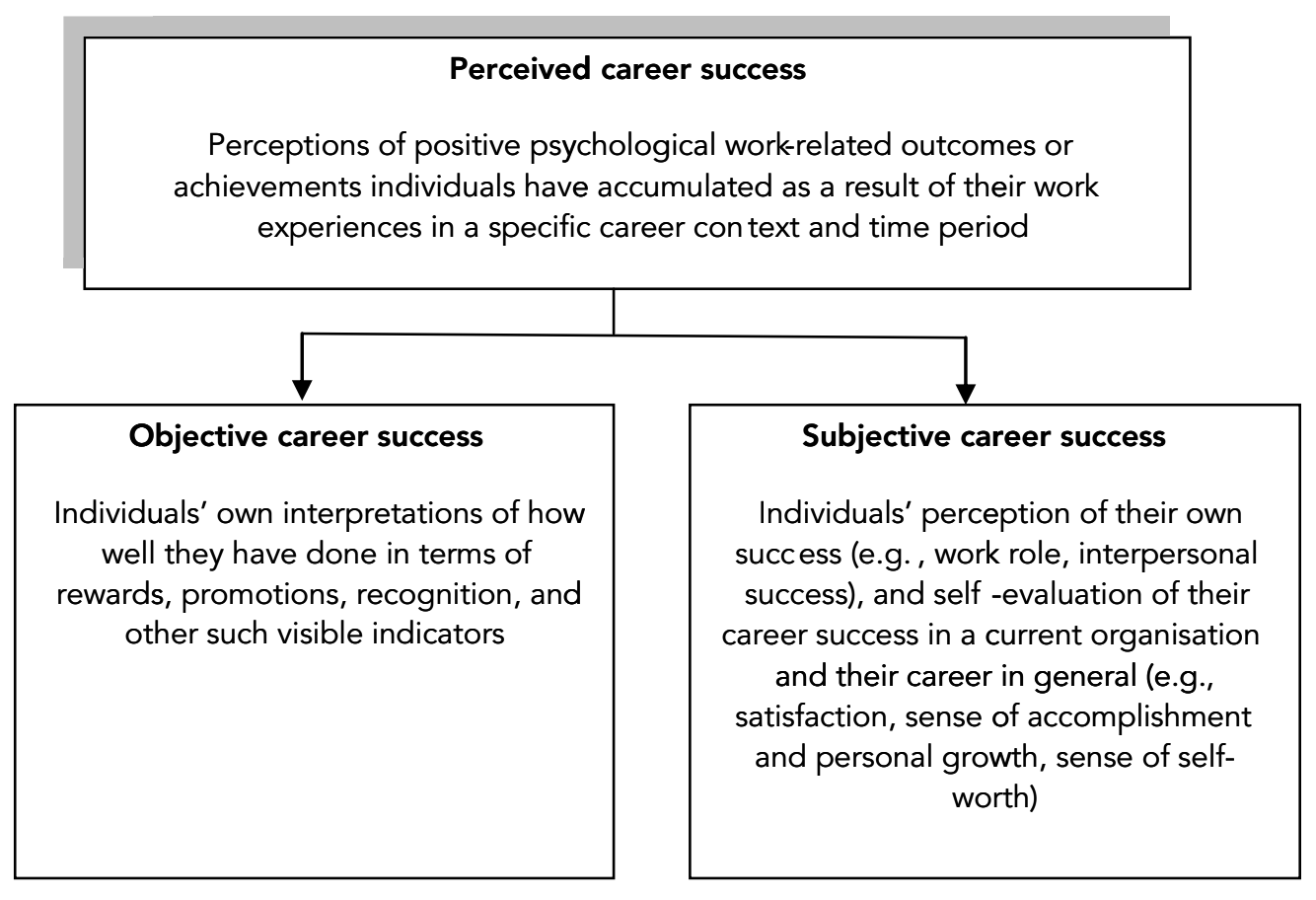

FIGURE 1

Theoretical overview of the constructs of perceived career success. 
The objective career provides the work experiences that hypothetically influence individuals' subjective views of their career situation. Conversely, the attitudes and motivation of the subjective career may be hypothesised to influence a person's objective career as it is seen by others (Khapova et al., 2007). Although objective and subjective career success tend to be positively but moderately related (Judge, Cable, Boudreau, \& Bretz, 1995), the two are distinct concepts. Individuals who perceive themselves to be successful according to the objective criteria of pay and promotion may report less subjective career satisfaction than objectively less successful colleagues (Judge, et al., 1995). Many successful professionals, despite their high status and salaries, still reported low subjective perceptions of career success (Korman, Wittig-Berman, \& Lang, 1981). Career success is also situation- and time-dependent (Khapova et al., 2007). Research indicates that career success is not a constant or a static concept. Instead it reflects a sequence of events and represents a constantly changing construct (Kidd, 2008). In a new setting and culture, people may judge their objective success differently from the way they judged it in their previous jobs. Similarly, their own subjective criteria may evolve and change with the experience of a new situation (Peiperl \& Jonsen, 2007).

\section{Measurement Issues}

Subjective career success is therefore measured through establishing individuals' personal points of view that relate to a broad set of criteria that may or may not include factors such as remuneration and job level, but usually include concepts such as wellbeing and emotions. Kidd (2008) identified eight factors that are related to people's subjective career success or career wellbeing: career transitions, interpersonal relationships, relationship with the organisation, work performance, sense of purpose, learning and development and work-life issues. The inclusion of a wider range of concepts in the consideration of career success is increasingly important as individuals seek integration between their work and personal lives (Park, 2010). An increasing understanding of individuals' perceptions of their career success may therefore contribute new and valuable research to the field and practice of careers in the high technology environment.

\section{Goals of the Study}

This study, therefore, sets out to explore the core themes underlying individuals' perceptions of their career success with the view to inform human resource practices for retaining staff with high technology skills in the science and engineering environment. Ballout (2009) emphasises the importance of knowing and understanding the factors underlying individuals' perceptions of career success, especially for organisations focused on retaining motivated and competent employees.
Within the context of the current research the focus falls specifically on establishing these various meanings in order to better understand how individuals perceive and interpret the notion of career success in the science and engineering field. The study thus explores individuals' perceived career success. The focus is in line with current research trends that concentrate on studying career success from a subjective and personal perspective (Heslin, 2003, 2005; Kidd, 2008; Sinclair, 2009).

The research question posed for the study was: What core themes underlie employees in the science and engineering field's perceptions of their career success?

\section{Method}

\section{Research Strategy}

This study is regarded as exploratory research designed to gain insight and comprehension regarding the perceived career success of a sample of individuals employed by a science and engineering company. As the main objective of the study was to gather data for broad exploratory purposes, a qualitative interpretivist epistemology approach (Denzin \& Lincoln, 2000) was used. This approach emphasises individuals' engagement in the process of making sense of their (life) worlds and their continuous involvement in giving meaning to, creating and interpreting their actions (Babbie \& Mouton, 2009).

\section{Partcipants and Setting}

A nonprobability convenience sample of 207 full-time employed adults (63\% Blacks; $60 \%$ males) specialising in the science and engineering field participated in the study. They were predominantly in their early career life stages, with $46 \%$ of the sample being between the age of 26 and 40 years old, $37 \%$ of the sample was 25 years and younger, $14 \%$ were aged between 41 and 55 years, and 3\% of the sample was 56 years and older. The participants reported a relatively high educational level with $26 \%$ having attained postgraduate level qualifications and $47 \%$ having attained a degree, diploma or certificate-level higher education qualification.

\section{Data Collection Methods}

Data were gathered by using a quantitative survey approach and posing an open-ended question to the participants regarding their perceived career success. The question read thus:

- Do you feel that you have achieved career success? Explain your answer by briefly describing the elements or aspects of your career that will make you feel that you have achieved career success.

Prior to the study, the question was reviewed by another subject expert in the field and piloted with 20 participants for clarity and relevance. 


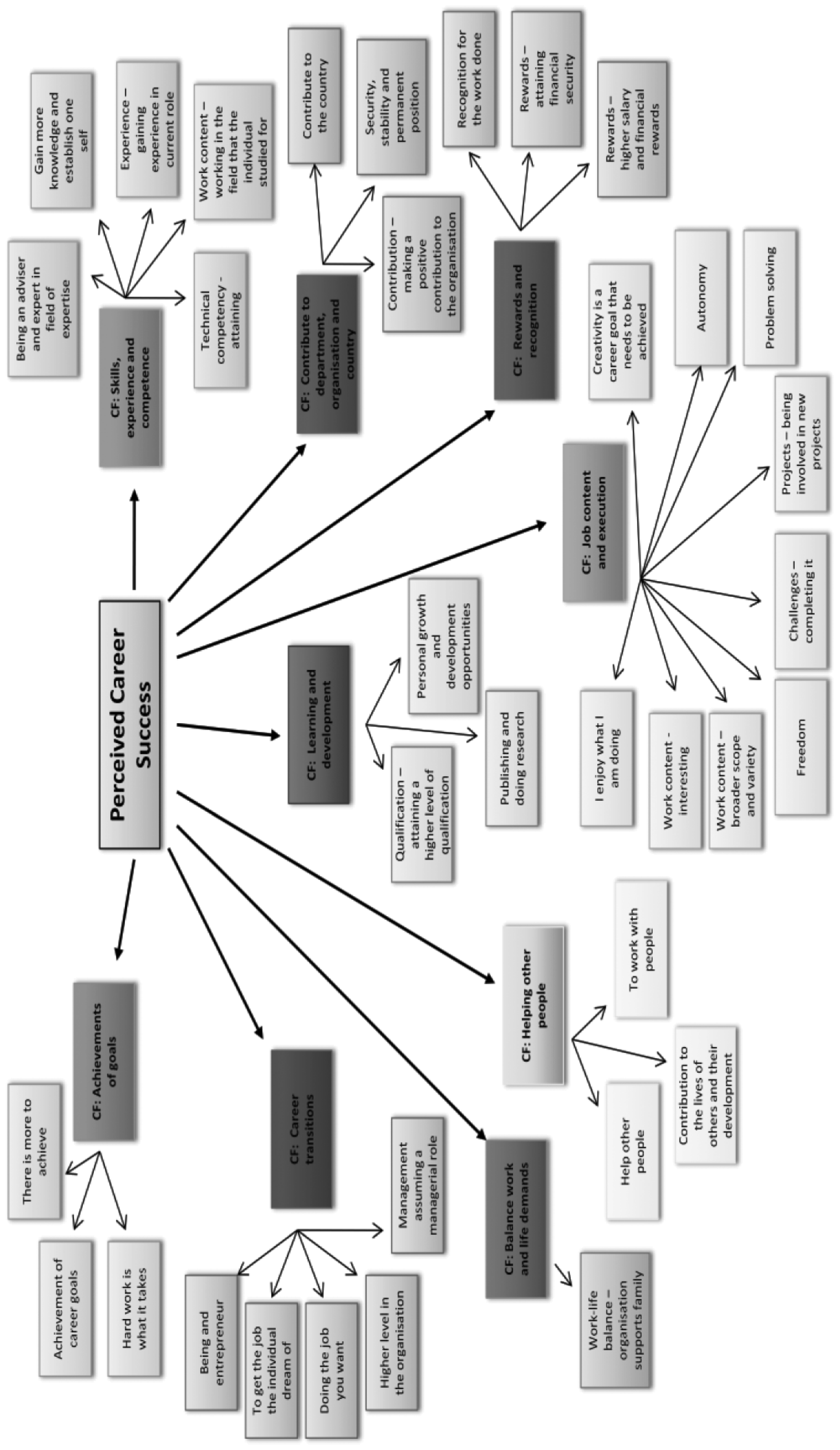

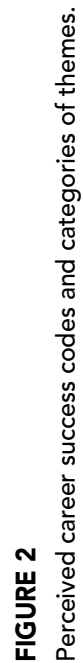


TABLE 1

Summary of Perceived Career Success Categories, Codes and Quotes

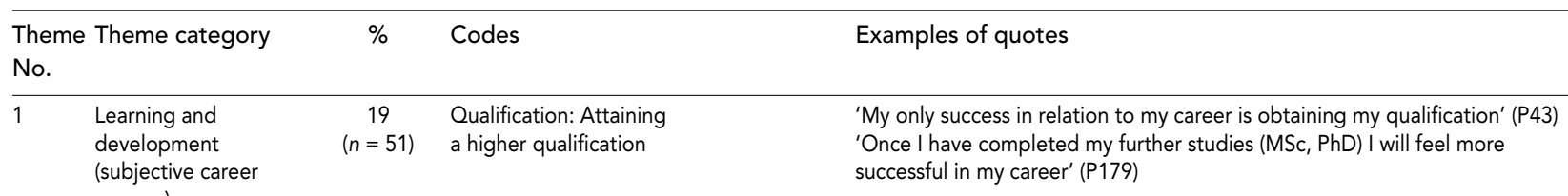

Personal growth and development 'Excellency in what I do and developing other skills would definitely be career success for me' (P104)

success) Personal growth and development

'Working in an environment where personal growth is encouraged' (P48)

Publishing and doing research 'I would like to, at least, develop a decent record of publications and better skills at research' (P183)

'I was able to write a number of good papers with friends I have great esteem for and I was and actually am still able to progress science forward' (P105)

\begin{tabular}{llc}
\hline 2 & $\begin{array}{l}\text { Skills, experience } \\
\text { and competence } \\
\text { (subjective career } \\
\text { success) }\end{array}$ & $\begin{array}{c}18 \\
(n=48)\end{array}$ \\
& \\
\hline 3 & $\begin{array}{l}\text { Career transitions/ } \\
\text { advancement } \\
\text { (objective career } \\
\text { success) }\end{array}$ & 16 \\
& $(n=43)$
\end{tabular}

Gain more knowledge and establish oneself

Work content: Working in the field that the individual studied for

'Career success would mean being an adviser in the field and being ahead of expertise of recent developments' (P178)

'Being regarded as an expert/authority in my field of research is the ultimate career success' (P179)

'My knowledge and expertise needs to be fully utilised'

Attaining technical competency

'Getting a relevant job to the field I have studied for' (P235)

'... only if I get a permanent job for the field that I have studied in University' (P237)

Attaining technical competency I believe that I have established myself as a technically competent individual' (P146)

'I was given the opportunity to achieve technical competency during the first 20 years of my career' (P236)

Experience: Gaining experience 'I do not have enough experience to say I have achieved career success' in current role (P104)

Being an entrepreneur

'I would like to see my own business grow bigger' (P55)

'I would like to start my own business' (P60)

'...being an entrepreneur' (P240)

To get the job the individual dreams of

'I did not achieve career success, because I did not follow my dream life' (P182)

Doing the job you want

....this is not quite the kind of job I want to do for the rest of my life' (P59)

'Because the career I am in now is not the career I want to be in' (P56)

Higher level in the organisation 'It's difficult to tell at the moment because I am on a low level, but if I get the promotion in July I'll feel career success' (P70)

'If I could advance my current career to maybe a higher level, I would fee that I have achieved career success' (P89)

'I feel I have reached a ceiling in my career at the organisation. I will probably have to leave the organisation to move up' (P155)

Management: Assuming a

'... be in a managerial position' (P196)

managerial role

'Elements to be successful include more responsibility, larger projects, management and higher salary expectations' (P230)

\begin{tabular}{llc}
\hline 4 & $\begin{array}{l}\text { Job content } \\
\text { (subjective career } \\
\text { success) }\end{array}$ & 15 \\
$(n=40)$
\end{tabular}

I enjoy what I am doing

Work content: Interesting

'I enjoy my work' (P130)

'I enjoy what I am doing' (P242)

'I also have yet to find an area of work that I am fully interested in' (P234)

Work content: Broader scope

'I think I can do better if I can broaden my scope' (P127)

Freedom

'I would like to have freedom and be allowed to be innovative in fulfilling the requirements of my position' (P195)

Completing challenges

'I will feel and does feel successful when I look back after completing a challenge' (P226)

Projects: Being involved in new projects 'I must be in a position where I define projects and I complete them in the required time' (P203)

Problem-solving

'...experience my passion and knowledge in solving problems and passing knowledge' (P177)

'I love being put in situations where I have to use my knowledge and skills to overcome problems' (P215)

Autonomy

Creativity is a career goal that

'... because I don't like to be supervised my entire life' (P240)

needs to be achieved

'I would like to be distinguished, both creatively and professionally' (P103)

'I have a career where more or less I am limited by my own energy or creativity' (P211) 


\section{TABLE 1 (CONTINUED)}

Summary of Perceived Career Success Categories, Codes and Quotes

\begin{tabular}{|c|c|c|c|c|}
\hline \multicolumn{2}{|c|}{$\begin{array}{l}\text { Theme Theme category } \\
\text { No. }\end{array}$} & \multirow{2}{*}{$\begin{array}{c}\% \\
11 \\
(n=30)\end{array}$} & $\begin{array}{l}\text { Codes } \\
\text { Contribute to the country }\end{array}$ & $\begin{array}{l}\text { Examples of quotes } \\
\text { '...my efforts have made a real contribution to the country' (P92) } \\
\text { '...make a contribution to the economic growth of the country' (P165) }\end{array}$ \\
\hline \multirow[t]{4}{*}{5} & \multirow[t]{4}{*}{$\begin{array}{l}\text { Contribute to } \\
\text { department, } \\
\text { organisation and } \\
\text { country } \\
\text { (subjective career } \\
\text { success) }\end{array}$} & & \multirow[t]{2}{*}{$\begin{array}{l}\text { Security, stability and permanent } \\
\text { position }\end{array}$} & $\begin{array}{l}\text { '...my efforts have made a real contribution to the country' (P92) } \\
\text { '...make a contribution to the economic growth of the country' (P165) } \\
\text { 'I would like to have a more stable, permanent, senior position in my current } \\
\text { job role/function with more scope for career development and professional } \\
\text { opportunities' (P230) } \\
\text { 'I am still on a contract job. I would achieve success in my career only if I get } \\
\text { a permanent job' (P237) }\end{array}$ \\
\hline & & & & 'I am a contract worker therefore there is no security and stability' (P42) \\
\hline & & & \multirow[t]{2}{*}{$\begin{array}{l}\text { Contribution: Making a positive } \\
\text { contribution to the organisation }\end{array}$} & $\begin{array}{l}\text { 'I will feel that I have achieved career success when I feel that my presence } \\
\text { at work all day is fundamental, my absence is noticed. That means develop- } \\
\text { ing abilities and strategies making the company go forward' (P164) }\end{array}$ \\
\hline & & & & '...feel like I am making a positive contribution to the organisation' (P242) \\
\hline 6 & $\begin{array}{l}\text { Achievement } \\
\text { of goals } \\
\text { (subjective career } \\
\text { success) }\end{array}$ & $\begin{array}{c}10 \\
(n=27)\end{array}$ & $\begin{array}{l}\text { There is more to achieve } \\
\text { Achievement of career goals } \\
\text { Hard work is required }\end{array}$ & $\begin{array}{l}\text { 'I don't feel that I am where I want to be as yet' (P229) } \\
\text { 'So far I have achieved all the career goals that I set out for myself' (P233) } \\
\text { '...but still feel like I need to work hard to achieve career success' (P151) }\end{array}$ \\
\hline \multirow[t]{2}{*}{7} & \multirow[t]{2}{*}{$\begin{array}{l}\text { Helping other } \\
\text { people } \\
\text { (subjective career } \\
\text { success) }\end{array}$} & \multirow[t]{2}{*}{$\begin{array}{c}5 \\
(n=14)\end{array}$} & $\begin{array}{l}\text { Help other people } \\
\text { Contribution to the lives of others } \\
\text { and their development }\end{array}$ & $\begin{array}{l}\text { 'I love training and I feel fulfilled when I am able to help people' (P95) } \\
\text { 'I want to see myself helping people more on developing themselves at } \\
\text { work places and with their life style' (P167) } \\
\text { '...make a positive difference in the lives of colleagues and subordinates by } \\
\text { assisting them to grow and increase their standards of output' (P236) }\end{array}$ \\
\hline & & & To work with people & 'I had the opportunity to work with people' (P136) \\
\hline \multirow[t]{2}{*}{8} & \multirow[t]{2}{*}{$\begin{array}{l}\text { Rewards and recognition } \\
\text { (objective career success) }\end{array}$} & \multirow[t]{2}{*}{$\begin{array}{c}4 \\
(n=11)\end{array}$} & $\begin{array}{l}\text { Recognition for the work done } \\
\text { Rewards: Attaining financial security }\end{array}$ & $\begin{array}{l}\text { 'I will feel success when I get recognition for the hard work I put in' (P102 } \\
\text { 'financial and employment security' (P207) }\end{array}$ \\
\hline & & & $\begin{array}{l}\text { Rewards: Higher salary and financial } \\
\text { rewards }\end{array}$ & $\begin{array}{l}\text { '...success is based on the salary you earn' (P23) } \\
\text { 'It is because my pay does not show how hard I work and I do not deserve } \\
\text { what I am paying because it is too little in my eyes' (P172) }\end{array}$ \\
\hline \multirow[t]{2}{*}{9} & \multirow[t]{2}{*}{$\begin{array}{l}\text { Work-life balance } \\
\text { (subjective career } \\
\text { success) }\end{array}$} & \multirow[t]{2}{*}{$\begin{array}{c}2 \\
(n=5)\end{array}$} & \multirow[t]{2}{*}{$\begin{array}{l}\text { Work-life balance: Organisation } \\
\text { supports family }\end{array}$} & $\begin{array}{l}\text { 'I can only achieve career success, if I am at a stage where I am able to apply } \\
\text { my mind effortlessly and the company I work for support and encourage } \\
\text { family life' (P227) }\end{array}$ \\
\hline & & & & '...time, family and friends, to maintain and juggle those with ease' (P48) \\
\hline
\end{tabular}

\section{Procedure}

Ethical clearance and permission to conduct the study was obtained from the management of the organisation who participated in the research. Participation was voluntary and employees were given the opportunity of attending one of several allocated sessions. At the beginning of each session the researcher explained the purpose of the research and participants were assured of confidentiality and anonymity and the voluntary nature of participation. A covering letter was provided that explained the purpose of the research, procedure, potential benefits, confidentiality, anonymity, participation and withdrawal. All participants also completed a written consent form for using the data for research purposes only. Participants completed the questionnaires during a session allocated for this purpose and returned the completed questionnaires to the researcher and psychometrist who coordinated the session.

\section{Data Analyses}

The data were analysed using the Atlas.ti version 6 computer-aided qualitative data analysis software. The use of this package enabled the researcher to increase the rigour and manageability of the qualitative data (Babbie \&
Mouton, 2009). Although the Atlas.ti program assisted in the data analysis process, we performed supplemental manual data analysis to enhance the scope of findings. We used the hermeneutic-classificatory content analysis as proposed by Roller, Mathes and Eckert (1995).

The data were coded into categories of themes that emerged and networks of codes belonging to the particular categories were established. We also used literature control (du Toit, 2010) to interpret the data.

\section{Strategies Employed to Ensure Quality Data}

For data trustworthiness, we arranged peer debriefing sessions with a fellow researcher and subject expert from the researcher's work environment.

The criteria for dependability and confirmability were met by providing an audit trail (du Toit, 2010) through publishing the following categories of data on an accesscontrolled web site of the company who participated in the research:

- Raw data: the anonymous survey results were published.

- Data reduction and analysis products: the summaries, field notes and codes were published. 
- Data reconstruction and synthesis products: the categories (themes, definitions and relationships) and the final research report were published.

- Process notes: all designs and methodological notes were also published.

\section{Findings}

Figure 2 and Table 1 show that the data analysis yielded nine higher order categories of themes related to perceived career success: (1) learning and development (19\%); (2) skills experience and competence (18\%); (3) career transitions/advancement (16\%); (4) job content (15\%); (5) contribution to the broader community $(11 \%)$; (6) achievement of goals (10\%); (7) helping other people (5\%); (8) reward and recognition (4\%); and (9) work-life balance $(2 \%)$. These categories are described in detail below. Table 1 gives examples of typical responses made by the respondents to each of these themes.

\section{Theme 1: Learning and Development}

The main features of the learning and development category involved attaining a higher level of qualification, carrying out and publishing research and finally, personal growth and development opportunities. The learning and development category was prominent within this sample, which already boasted a high educational level. It seems likely that learning and development is very important within the respondents' work environment.

My only success in relation to my career is obtaining my qualification. (Participant \# 43)

Once I have completed my further studies (MSc, $\mathrm{PhD}$ ) I will feel more successful in my career. (P\#179)

Working in an environment where personal growth is encouraged. ( $\mathrm{P} \# 48$ )

I was able to write a number of good papers with friends I have great esteem for and I was and actually am still able to progress science forward. ( $\mathrm{P} \# 105)$

\section{Theme 2: Skills, Experience and Competence}

The skills, experience and competence category involved attainment of technical competency, working within the field that an individual had studied for, gaining more experience within the current role, gaining more knowledge and becoming established within the work environment and finally, being an adviser or an expert within a particular field of expertise.

My knowledge and expertise needs to be fully utilised.

I believe that I have established myself as a technically competent individual. (P\#146)

I was given the opportunity to achieve technical competency during the first 20 years of my career. (P236)

\section{Theme 3: Career Transitions/Advancement}

Career transitions/advancement involved progressing to a higher level within the organisation, being able to do desirable jobs, being an entrepreneur, assuming a managerial role.

It's difficult to tell at the moment because I am on a low level, but if I get the promotion in July I'll feel career success. (P\#70)

If I could advance my current career to maybe a higher level, I would feel that I have achieved career success. (P\#89)

Elements to be successful include more responsibility, larger projects, management and higher salary expectations. $(\mathrm{P} \# 230)$

\section{Theme 4: Job Content}

The job content category comprised a number of different respondent codes and included completing challenges, freedom in the execution of tasks, being involved in new projects, solving problems that seem unsolvable, interesting work, broad scope and variety in tasks, enjoyment of the job an individual is doing and autonomy and creativity in the execution of one's duties.

I will feel and does feel successful when I look back after completing a challenge. $(\mathrm{P} \# 226)$

I would like to have freedom and be allowed to be innovative in fulfilling the requirements of my position. (P\#195)

...experience my passion and knowledge in solving problems and passing knowledge. (P\#177)

I love being put in situations where I have to use my knowledge and skills to overcome problems. (P\#215)

\section{Theme 5: Contribution to the Broader Community}

This theme consisted of security, stability and having a permanent position within the organisation. It also involved making a positive contribution to the organisation and making a contribution to the country.

I would like to have a more stable, permanent, senior position in my current job role/function with more scope for career development and professional opportunities. (P\#230)

I will feel that I have achieved career success when I feel that my presence at work all day is fundamental, my absence is noticed. That means developing abilities and strategies making the company go forward. (P\#164)

..feel like I am making a positive contribution to the organisation. (P\#242)

...my efforts have made a real contribution to the country. (P\#92) 
...make a contribution to the economic growth of the country. (P\#165)

\section{Theme 6: Achievement of Career Goals}

Achievement of career goals consisted of the achievement of set career goals, the idea that there is always more to achieve and that hard work is required to achieve goals.

So far I have achieved all the career goals that I set out for myself. (P\#233)

...but still feel like I need to work hard to achieve career success. (P\#151)

\section{Theme 7: Helping Other People}

Helping other people also featured in the respondents' responses. This category included making a contribution to the lives of others and their development, helping other people and working with people.

I love training and I feel fulfilled when I am able to help people. (P\#95)

I want to see myself helping people more on developing themselves at work places and with their life style. (P\#167)

\section{Theme 8: Rewards and Recognition}

Rewards and recognition included attaining financial security and receiving a higher salary and financial rewards. The category also included recognition for work done.

I will feel success when I get recognition for the hard work I put in. (P\#102)

...success is based on the salary you earn. ( $\mathrm{P \# 23)}$

It is because my pay does not show how hard I work and I do not deserve what I am paying because it is too little in my eyes. (P\#172)

\section{Theme 9: Work-Life Balance}

The work-life balance theme involved a balance between work and personal life and organisational support with regards to family responsibilities.

I can only achieve career success, if I am at a stage where I am able to apply my mind effortlessly and the company I work for support and encourage family life. (P\#227)

...time, family and friends, to maintain and juggle those with ease. (P\#48)

\section{Discussion}

The objective of the study was to broadly explore the core themes underlying individuals' perceptions of their career success. In interpreting the findings, the specific research setting of the study and the biographical profile of the sample were taken into consideration. The respondents were predominantly professionally qualified Black and male staff employed full-time in a South African science and engineering company. The respondents were predominantly in the early (exploration and establishment) stage of their careers.

The qualitative data analysed revealed various themes underlying the respondents' perceptions of career success, thus confirming the multidimensional nature of the construct of career success (Nabi, 2003). In accordance with the research literature (Ballout, 2009; Cocchiara, Kwesiga, Bell, \& Baruch, 2010; Judge, Kammeyer-Mueller, \& Betz, 2004; Schreuder \& Coetzee, 2011; Sinclair, 2009), the identified themes related to both objective and subjective career success. In terms of objective career success, career transitions/advancement and reward and recognition were indicated as the dominant themes. According to Nabi (2003), favourable perceptions about organisational opportunities for career advancement provide powerful frames of references for employees. Future career prospects provide a sense of job security that is characterised by a sense of stability about one's job continuity. Job security often represents a dominant concern among employees that is likely to influence feelings of self-worth and the quality of one's work and life experiences (Kidd, 2008; Lin, 1996). Nabi (2003) found perceptions of favourable organisational career prospects and security to be significantly related to higher levels of perceived subjective career success.

The themes associated with subjective career success (Nabi, 2003; Khapova et al., 2007; Kidd, 2008; Peiperl \& Jonsen, 2007; Schreuder \& Coetzee, 2011) included learning and development, skills, experience and competence, job content, making a contribution to the department, organisation and country, achievement of goals, helping other people and work-life balance. The notion of career goal-setting (e.g., achieving career advancement, or learning and development goals) is generally a useful and purposeful process as it allows individuals to achieve their personal aspirations and goals (Nabi, 2003). Achievement of one's personal aspirations and goals constitutes an important aspect of feelings of career wellbeing and subjective career success (Kidd, 2008).

Research by Warr (2002) has also indicated the following perceived career success themes as being important for enhancing people's overall job satisfaction: opportunities to utilise one's knowledge and skills; performing enriched and a variety of challenging tasks (which help one to develop one's expertise and competence in solving problems); opportunities to contribute to the greater good of the department, organisation and society; opportunity for interpersonal contact and helping others; further learning and growth and occupying a valued social position. Coetzee and Schreuder (2008) further reported that the younger generation of people in the early life/career stage tend to be more concerned about lifestyle integration than the older generation. In this regard Coetzee et al. (2010) 
indicated lifestyle career values to be significantly related to subjective work experiences such as career and job satisfaction and perceiving work as meaningful.

The current research project confirms most of the themes identified by Döckel (2003) and Lesabe and Nkosi (2007) as critical factors in the retention of highly skilled, professional and managerial staff in a South African context. These include compensation (base salary), job characteristics (skill variety and job autonomy), training and development opportunities, supervisor support, career mobility and advancement opportunities and work-life policies. The findings of the present study are regarded as important for retention practices in the science and engineering environment in the light of the sample being predominantly young Black employees who, in terms of employment equity, form part of the South African scarce skills categories (Coetzee, 2010).

\section{Limitations and Recommendations}

Since the present study has been limited to a sample of mostly young Black and male respondents predominantly employed in the science and engineering industry in the South African organisational context, the findings cannot be generalised to other age and race groups, as well as organisational and occupational contexts. Furthermore, given the qualitative and exploratory nature of the research design, this study should be regarded as a preliminary investigation that may point to future empirically and quantitatively more robust studies. These findings therefore need to be replicated with broader samples across various age, race, organisational and occupational groups and economic sectors before final conclusions can be drawn about the meanings underlying individuals' perceptions of their career success. Furthermore, considering that perceptions of career success tend to evolve as career situations and circumstance change for individuals, longitudinal studies may be fruitful for future research. Further research could provide more stringent quantitative measures of career success by using longitudinal research methodology.

\section{Conclusions and Implications for Practice}

Overall, we conclude that the notion of career success is multidimensional in nature. In this regard, the findings highlight the need to examine or measure the construct of career success in terms of its multidimensional nature in future research endeavours. In addition, the identified themes appear to be closely related to aspects pointed out in the literature as being important in the retention of workers in the high technology work environment. This suggests that favourable organisational conditions that address the themes reported in the findings may invoke higher levels of subjective career success for the individuals who participated in this study.

Considering that research indicates a direct relationship between organisational career systems and subjective career success (Baruch, 2004, 2006; Nabi, 2003), the findings highlight the importance of integrating the identified themes in the company's career development and retention policies and practices. Organisational career systems that facilitate career success should be of interest to human resource practitioners concerned with employee wellbeing, satisfaction and retention. Given the scarcity of empirical work on the constructs of career success in the science and engineering environment, this study is regarded as contributing valuable new knowledge that may be useful in the design of human resource retention practices focused on the career development and satisfaction of staff skilled in high technology.

\section{References}

Arnold, J., \& Cohen, L. (2008). The psychology of careers in industrial and organisational settings: A critical but appreciative analysis. In G.P. Hodgkinson \& J.K. Ford (eds), International review of industrial and organisational psychology (Vol. 23, pp. 1-43). London: John Wiley \& Sons.

Arthur, M.B., Khapova, S.N., \& Wilderom, C.P.M. (2005). Career success in a boundaryless career world. Journal of Organizational Behavior, 26, 177-202.

Babbie, E., \& Mouton, J. (2009). The practice of social research: South African edition. Cape Town: Oxford University Press Southern Africa.

Ballout, H.I. (2009). Career commitment and career success: moderating role of self-efficacy. Career Development International, 14(7), 655-670.

Baruch, Y. (2004). Transforming careers: From linear to multidirectional career paths: Organisational and individual perspectives. Career Development International, 9(1), 5873.

Baruch, Y. (2006). Career developmentr in organizations and beyond: Balancing traditional and contemporary viewpoints. Human Resource Management Review, 16, 125-138.

Coetzee, M. (2010). The employment context and human resource planning. In M. Coetzee \& D. Schreuder (Eds.), Personnel Psychology: An applied perspective (pp. 45-85). Cape Town, South Africa: Oxford University Press.

Coetzee, M., \& Bergh, Z. (2009). Psychological career resources and subjective work experiences of working adults: An exploratory study. Southern African Business Review, 13(2), 1-31.

Coetzee, M., Bergh, Z.C., \& Schreuder, A.M.G. (2010). The influence of career orientations on subjective work experiences. South African Journal of Human Resource Management, 8(1). doi:10.4102/sajhrm.v8i1.279

Coetzee, M., \& Schreuder, A.M.G (2008). A multi-cultural investigation of students' career anchors at a South African higher education institution. South African Journal of Labour Relations , 32(2), 45-65.

Coetzee, M., \& Schreuder, D. (2011). The relation between career anchors, emotional intelligence and employability 
satisfaction among workers in the service industry. Southern African Business Review, 15(3), 76-97.

Cocchiara, F.K., Kwesiga, E., Bell, M.P., \& Baruch, Y. (2010). Influences on perceived career success: findings from US graduate business degree alumne. Career Development International, 15(1), 39-58.

Denzin, N.K., \& Lincoln, Y.S. (2000). The landscape of qualitative research: Theories and issues. Thousand Oaks, CA: Sage.

Döckel, A. (2003). The effect of retention factors on organisational commitment: An investigation of high technology employees (Unpublished MCom dissertation). University of Pretoria, South Africa.

Döckel, A., Basson, J.S., \& Coetzee, M. (2006). The effect of retention factors on organizational commitment: An investigation of high technology employees. South African Journal of Human Resource Management, 4(2), 20-28.

du Toit, D. (2010). The relationship between archetypal values, career orientations, perceived career success and meaningfulness. (Unpublished master's dissertation). University of South Africa, Pretoria.

Hall, D.T., \& Chandler, D.E. (2005). Psychological success: When the career is a calling. Journal of Organizational Behavior, 26, 155-176.

Heslin, P.A. (2003). Self and other referent critera of career success. Journal of Career Assessment, 11, 262-285.

Heslin, P.A. (2005). Conceptualizing and evaluating career success. Journal of Organizational Behavior, 26, 113-136.

Judge, T.A., Cable, D.M., Boudreau, J.W., \& Bretz, R.D., Jr. (1995). En empirical investigation of the predictors of executive career success. Personnel Psychology, 48, 485-519.

Judge, T.A., Kammeyer-Mueller, J., \& Betz, R.D. (2004). A longitudinal model of sponsorship and career success: a study of industrial-organizational psychologists. Personnel Psychology, 57, 271-303.

Khapova, S.N., Arthur, M.B., \& Wilderom, C.P.M. (2007). The subjective career in the knowledge economy. In $\mathrm{H}$. Gunz \& M. Peiperl (eds), Handbook of career studies (pp. 114-130). London: Sage.

Kidd, J.M. (2008). Exploring components of career wellbeing and the emotions associated with significant career experiences. Journal of Career Development, 35(2), 166-186.

Korman, A.K., Wittig-Berman, U., \& Lang, D. (1981). Career success and personal failure: alienation in professionals and managers. Academy of Management Journal, 24(2), 342-360.

Kuznia, K.D., Kerno, S.J., Jr., \& Gilley, A. (2010). The correlates and influences of career-related continuous learning: implications for management professionals. Performance Improvement Quarterly, 22(4), 7-31.

Lesabe, R.A., \& Nkosi, J. (2007). A qualitative exploration of employees' views on organisational commitment. South African Journal of Human Resource Management, 5(1), 35-44.

Lin, V.K.G. (1996). Job insecurity and its outcomes: moderating effects of work-based and non-work based social support. Human Relations, 49(2), 171-194.

Murphy, C. (2000). The survey says: Lots of IT jobs, not enough workers. Information Week, 782, 152.

Nabi, G.L. (2003). Situational characteristics and subjective career success. International Journal of Manpower, 24(6), 653-671.

Park, Y. (2010). The predictors of subjective career success: an empirical study of employee development in a Korean financial company. International Journal of Training and Development, 14(1), 1-15.

Peiperl, M., \& Jonsen, K. (2007). Global careers. In H. Gunz \& M. Peiperl (Eds.), Handbook of career studies (pp. 350372). London: Sage.

Peluchette, J. (1993). Subjective career success: The influence of individual difference, family, and organisational variables. Journal of Vocational Behavior, 43, 198-208.

Powell, W.W., \& Snellman, K. (2004). The knowledge economy. Annual Review of Sociology, 30, 199-220.

Rogers, E.W. (2001). A theoretical look at firm performance in high technology organisations: What does existing theory tell us? Journal of High Technology Management Research, 12, 39-61.

Roller, E., Mathes, R., \& Eckert, T. (1995). Computer-aided qualitative data analysis: Theory, methods and practice. London: Sage.

Schreuder, A.M.G., \& Coetzee, M. (2011). Careers: An organisational perspective (4th ed.). Cape Town, South Africa: Juta.

Sinclair, V. (2009). Experiencing career satisfaction and career success over the life span. Retrieved from http://www.counselling-directory.org.uk/counselloradvice98889.html

Von Glinow, M.A., \& Mohrman, S.A. (1990). Attachment and withdrawal patterns of high technology workers. Journal of High Technology Management Research, 1(2), 149-165.

Warr, P.B. (2002). The study of well-being, behavior and attitudes. In P.B. Warr (Ed.), Psychology at work (pp. 1-25). London: Penguin. 